\title{
Studies on Electron Beam Curing of $\begin{aligned} & \text { UDC } \\ & 667.645 .32 .085 \\ & : 667.633 .263 .3\end{aligned}$ \\ Unsaturated Polyester- $: 667.633 .263 .3$
$: 668.674^{\prime} 428^{\prime} 42$ \\ Monomer Systems. I.
}

\author{
Hitoshi Kaminke, Hiroshi Takahashi \\ and Takao Kageyama \\ Nippon Paint Co., Ltd.*
}

\begin{abstract}
In order to find the optimum conditions for electron beam curing of coatings, the effects of dose rate on curing velocity of unsaturated polyester-monomer systems were studied. The polyesters were prepared from maleic acid, phthalic acid and propylene glycol with the acid value of 42 to 72 . The monomers were styrene, methyl methacrylate, diallyl phthalate and vinyl acetate. Four accelerators of 0.8 to $6 \mathrm{MeV}$ delivering $0.025 \sim 1.43 \mathrm{Mrad} / \mathrm{sec}$ were employed. The extent of cure of irradiated material was evaluated by measuring gel fraction.

It was found that many of the systems studied were cured sufficiently by irradiation of 3 to $9 \mathrm{Mrad}$, most of which at about 6 Mrad. Curing velocity was proportional to the 0.5 to 0.9 th power of dose rate. It appears that coating compositions curable at $3 \mathrm{M}$. rad can be formulated.
\end{abstract}

* Ouazaikeda, Nemugawa 


\title{
加速電子線昭射に上る不飽和ポリエステル 6067.645 .32 .085 \\ 加速電子線照射による不飽和ホリエステルー: 667.633 .263 .3 モノマー系の硬化 (第 $\mathbf{1}$ 報)
}

\author{
上池齊*・高橋宏*・影山孝夫*
}

要旨

放射線特に加速電子線の工業利用の中, 塗料の硬化に用いることは, 対象がきわめて薄層で あるという点で従来の利用と性格が大きく異なる。薄い塗膜で吸収されるエネルギー効率を高 め, 余分の透過電子線による素地への悪影響を少なくするとともに, 反応が十分早く起こるた めには, 加速電圧は低く電子電流は大きいのが有利である。一般に線量は電子線の有効飛程に ついて計算されるが，塗膜はこの飛程に比べてはなはだ薄いので正確な線量の計算はむつかし い。このような場合の線量の取り扱いについていくらかの考察を加えた。

電子線硬化用塗料の開発にあたって基礎的な反応の機構を把握するために, 典型的な不飽和 ポリエステルーモノマー系の照射実験を行なった。主として研究用の汎用加速器を用いた実験 から次の結果が得られた。

（1）硬化度の判定にはバル分率の測定が有効な方法であると認められる。

（2）一般に不飽和ポリエステルーモノマー系組成は総線 量 3〜9 Mrad で硬化し，中でも $6 \mathrm{Mrad}$ 前後で実用硬化状態に達するものが多い。

（3）実験した範囲では硬化速度は 0.5 0.9 乗の範囲で線量率に依存する。

（4）線量率依存性・硬化線量は系の組成により異なる。また $3 \mathrm{Mrad}$ 程度で硬化し, 塗料 としての実用性をもった組成は容易に開発でさると考觉る。

\section{1. 緒言}

原子力工業や電子機器工業の発展に伴って, 原子恼・ 放射性同位元素・粒子加速器などを線源とする放射線エ ネルギーの利用開発が進んでいる。すでに実用化された ものとして高分子改質・臭化エチルなどの有機合成・食 品の殺菌などが市り，さらに木材へのグラフト・繊維加 工・放射線キュアリング・高分子合成などが開発されつ つある1)。これらの中で被覆材料に関係するものとして 塗膜の放射線硬化の研究がさかんである2)。

塗料基材となる放射線重合性物質の代表的なものに不 飽和ポリエステルーモノマー系組成があり, 多くの研究 が発表されている。放射線硬化用塗料の基材としてはほ がもいろいろ考光られるが，この系は開発のいとぐち として重要なものであり, しかも反応機構解明のために 行なわ的た低線量率域の照射から工業生産のための高線 量率域の照射にかけての硬化の挙動については十分なデ 一タは発表されていない。したがってわれわれは放射線

昭 43.11 .8 受理

*日本ペイント株式会社中央研究所

寝屋川市大字池田旧池田中 246
硬化用塗料の開発にあたって, まず最初に典型的な不飽 和ポリエステルーモノマー系組成の硬化挙動を追試した。 その結果の一端を述べ，いくつかの考察を試みたい。

\section{2. 不飽和ポリエステルーモノマー系の放射線} 硬化

マレイン酸を主な不飽和成分とする不飽和ポリエステ ル技よびそれを重合性モノマーと混合した系は放射線照 射によって橋カケして不溶性ゲルを生成し, 塗料基材と して好ましいものである。Charlesby らは $\mathrm{Co}^{60}$ やバン デグラフ加速器で $10^{3} \sim 10^{8} \mathrm{rad} / \mathrm{min}$ の照射を行ない, この系はラジカル重合反応により硬化し，ポリエステル 間を橋カケするモノマーの鎖長は短かく，ポリエステル の構造や分子量の影響は少ないことを示しだ)。Burlant と Hinsch は赤外分光によりポリエステル特よびスチレ ンの二重結合の減少を追跡し，反応はポリエステルの活 性点に対するスチレンのグラフトで進行し，スチレンの 鎖長は短かく，反応速度は $10^{3} \mathrm{rad} / \mathrm{min}$ 以下では線量率 の $1 / 2$ 乗に比例するがそれ以上では線量率依存性が失わ れる傾向にあるとしだ)。Hoffman 预よび Smith は ICT-500による照射で不飽和ポリエステルに対するスチ 
レン, エチルアクリレート,メチルメタクリレートの組 み合せの硬化を調ベ，モノマーの種類とポリェステルに 対する比率によってゾル・ゲルの生成が大きく変るこ と, 線量率が高くなるとゲル生成速度が上昇し, 酸素の 抑制作用が問題とならなくなることを示した5)。これら の研究により，この反応に物いてはモノマーとそれがグ ラフトすべきポリエステルの不飽和基間の反応性と相対 濃度, ならびに硬化に対する線量率の影響が実用上重要 なポイントであることが考えられる。

不飽和ポリエステルーモノマー系は触媒硬化により木 工塗料としてすでに多量に使用されている。したがって 木工分野は実用化の第一の対象と考えられる6)。実用を 前提として, Charlesby らの研究から Tube Investments 社のもつ英国特許 ${ }^{8)}$ が, また Burlant やHinsch の研究 から Ford 社のもつ米国特許 ${ }^{9}$ が成立しており, 日本に 打いても放射線高分子研究協会に持ける重松らの研究7) に基づいた日本特許 ${ }^{10)}$ があり, 現在日本原子力研究所が 保有している。

\section{3. 線量計算と膜厚の関係についての考察}

放射線化学に沏いては照射をはかる尺度として照射を らけた物質が吸収したエネルギーを用いる。物質 $1 \mathrm{~g}$ 当 たり $100 \mathrm{erg}$ の吸収を単位 $\mathrm{rad}$ とする線量 (Dose) で 示すのが普通である。すなわち $E \mathrm{keV} て ゙ ~ i \mathrm{~mA}$, 出力 $E \cdot i$ ワットの電子線を $t$ 秒間照射した場合に物質 $X \mathrm{~g}$ によってその全部が吸収されたとすると線量は次式で示 される。

$$
D=\frac{E \cdot i}{X} \times t \times 10^{5} \mathrm{rad}
$$

物質中を通過した電子線はイオンやラジカルの生成, 二 次電子やX線への転換などでエネルギーを失らが，その 作用の強さは物質中で一様には減衰せず, 図-1 に示す ような曲線を画く ${ }^{11,12)}$ 。図の $R$ すなおち最大飛程は電子 のエネルギーレベルすなわち加速電圧によって決まる。 $R$ よりも厚い物質層を考えると飛程外の部分は吸収に関 与しないから線量は電圧によって定まる表面のある厚み

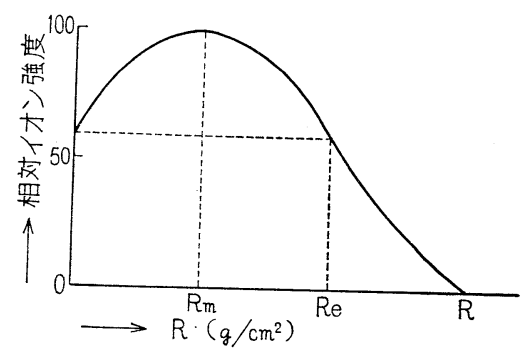

図-1 Depth-Dose 曲線
に集中する。逆に $R$ より薄い物質層を考皇ると曲線のそ の位置より右側の部分は貫通して損失となるからそれよ り左側の部分のエネルギーを吸収したものとし計算せね ばならない。図-1 の曲線は物質内で電子から受けるエ ネルギーの強度分布とみなせるから，積分計によって曲 線で囲まれた面積に対する $R$ の各位置での面積フラクシ ヨンを求めると図-2 に示す累積曲線が得られる。この 線は直線ではないので, 線量は厚みに対して一定ではな いことがわかる。図-2 で 0 から $R_{i}$ にいたる厚みの部 分がうける線量は $U_{i} / R_{i}$ に依存して相対的に分布し, $R_{i}$ の位置での線量の相対值はその点の $U$ 曲線のこう配 で示される。

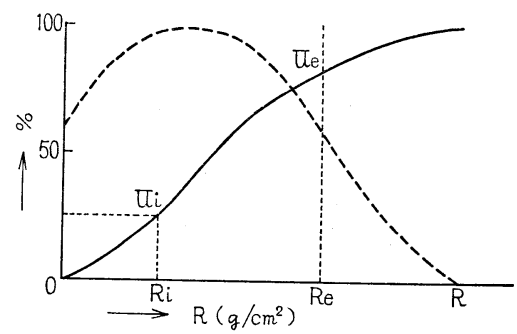

図-2 累積エネルギー利用率

図-1 の $R$ に相対する厚みの物質量に照射すればエネ ルギーの全部を利用できるが， $R$ の近くでは線量分布は 実質的にゼロとなり，反応の不均一を招く。このため入 射面とエネルギー強度が等しくなる $R_{e}$ の点を選んでこ れを有効飛程といい, 次式で表わされる線量を有効線量 とい5。

$$
D=\frac{E \cdot i}{R_{e} \cdot S} \times U_{e} \times 10^{5} \mathrm{rad} / \mathrm{sec}
$$

ただし $S$ は照射全面積 $\mathrm{cm}^{2}$ であり，1秒間の照射でうけ る線量すなわち線量率 (Dose rate) で表わしてある。 $R$ (または $R_{e}$ ) は厚さ $d \mathrm{~cm}$ と密度 $\rho \mathrm{g} / \mathrm{cm}^{3}$ の積すな わち面積密度 $\mathrm{g} / \mathrm{cm}^{2}$ を単位とする。これが一般にいわ れる線量である。加速器で電磁的に走査される電子線は 全面積について均一ではないので, 均一な部分だけを利 用すると照射面積内での損失を生じる。この利用効率を $f_{A}$ とし，(2) 式に扮いて厚みを任意の $R_{i}$ としその時の $U_{i}$ をあらためて $f_{D}$ とすれば (2) 式は次のように一般 化される。

$$
D=\frac{E \cdot i}{R_{i} \cdot S} \times f_{A} \times f_{D} \times 10^{5} \mathrm{rad} / \mathrm{sec}
$$

実際の線量算出にあたっては（3）式の $f_{A} \cdot f_{D}$ にあた る係数を実験的に求める。通常は線量として $R_{i}=R_{e}$ の 場合の值を求めるが, その場合 $0.7 \sim 15 \mathrm{MeV}$ の範囲で は経験的に $E / R_{e} \fallingdotseq 3$ が成立するので ${ }^{12)}$, 他の損失の係 
色材，42（1969）加速電子線照射による不飽和ポリエステルーモノマー系の硬化(第1 報)

数をまとめて $k$ とすると，

$$
D=\frac{3 k \cdot i}{S} \times 10^{5} \mathrm{rad} / \mathrm{sec}
$$

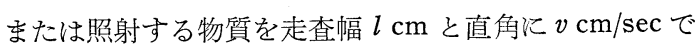
移動すると 1 秒間に照射をうける物質量は $R_{e} \cdot v \cdot l$ とな るから,

$$
D=\frac{3 k \cdot i}{l \cdot v} \times 10^{5} \mathrm{rad}
$$

という簡単な式を用いることが多い。

塗膜の電子線照射では物質層の厚みが $R_{e}$ に比しても きわめて薄い。たと党ば $1 \mathrm{MeV}$ の電子線では $R_{e}=0.33$ $\mathrm{g} / \mathrm{cm}^{2}$ すなわち密度 1 として $3,300 \mu$ であり, 図 -2 か らエネルギー利用效率がきわめて低いばかりでなく，実 質線量も $R_{e}$ から計算した值よりも低い。したがってこ の目的には低エネルギー（500 keV 以下）の電子線を用 い, そのため出力の低下を補なうために大電流（数十 $\mathrm{mA}$ ) の加速器が適切である。

実際の塗膜照射では電子線は塗膜に入射するまでに加 速管の金属の空と空気層を通過し，それぞれの層に拈い てェネルギーを失う。このような多層照射に拈いては, たとえば図-3 のように新しい物 質層に入射するごとに 新しいDepth-Dose 曲線を描くのが正しいとされ，図-1 に和いて $0 \rightarrow R$ の間に各層に相当する面積密度を想定し てェネルギーを配分するのは妥当ではない。しかし図-3 に示すような多層照射の各層での線量計算はまだ専門的 には行なわれて扣らず, 二つの Depth-Dose 曲線 $S_{1} \cdot S_{2}$

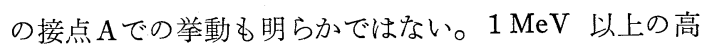
エネルギーの場合は塗膜入射前の損失は無視し得るほど 小さいと考えてよいから，すでに述べた諸式による線量 が成立するとしてよいであろう。しかし $500 \mathrm{keV}$ 以下の 低エネルギー照射の場合は図-3 の $R_{0}$ にあたる位置は無 視できず，またDepth-Dose 曲線自体も図-1 の形がそ のまま低エネルギーでも成立していると限らないので, 専門的に研究解明されることが望まれる。

以上述べたよ5に, 塗膜の電子線照射に括いて従来の $\mathrm{MeV}$ 単位の加速器で有効飛程を対象に計算された線量

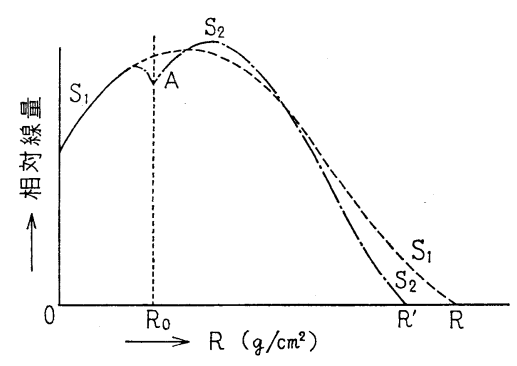

図-3 積層照射のエネルギー分布
を照射尺度とするのには疑問がある。しかし正確な取り 扱い方は明らかでなく, 本報の実験では比較的高エネル ギーで厚膜の照射を行なっているので，一般に使用され ている線量計算の值を用いた。( $\left.1 \mathrm{Mrad}=10^{6} \mathrm{rad}\right)$

\section{4. 実験 I ゲル分率による硬化判定}

不飽和ポリエステル系の硬化度の判定にゲル分率を用 いることは Alt や後藤らによって提唱されている ${ }^{13,14)}$ その方法に従い, 加水分解法拉よび溶剂抽出法によって 硬化試料のゲル分率を次式により求めた。

$$
G . F .=\frac{\text { 加水分解または溶剂抽出残分 }}{\text { 採 取 試 料 }} \times 100
$$

溶剤はアセトン・ベンゼンの容量比 $4: 6$ の混合物を用 い, $60^{\circ} \mathrm{C}$ で 15 時間抽出した。

試料は表-1 に示す組成のもので，ポリエステルは常 法により調製し，モノマーは新たに蒸留することなくそ のまま用いた。触媒硬化のコントロールは $3 \%$ ナフテン 酸コバルト $1 \%$ と MEKPO 1\%を加え 48 時間室温硬 化させたものを用いた。試料はアルミ製シャーレに厚さ 約 $1 \mathrm{~mm}$ に均一に入れ, 線型加速器で次の条件により室 温大気中で照射した。

電子エネルギー : $6 \mathrm{MeV}$

平均電子電流 : $50 \mu \mathrm{A}$

最大パルス電流: 最大 $400 \mathrm{~mA}$, パルス幅 $5 \mu \mathrm{sec}$, インターバル $32 \mathrm{~m} \mathrm{sec}$

照 射 線 量: $1.5,3,6,9 \mathrm{Mrad}$

\begin{tabular}{|c|c|c|c|c|c|c|c|}
\hline \multirow{2}{*}{ 区分 } & \multirow{2}{*}{ 記号 } & \multicolumn{3}{|c|}{ ポリエステル } & \multirow{2}{*}{$\left|\begin{array}{l}\text { ポリエ } \\
\text { ステル } \\
\text { 酸価 }\end{array}\right|$} & \multirow{2}{*}{$\begin{array}{l}\text { モノ - } \\
\text { (比 率) }\end{array}$} & \multirow{2}{*}{$\begin{array}{l}\text { 不飽和 } \\
\text { 基モル } \\
\text { 比 }\end{array}$} \\
\hline & & M A & P A & $P G$ & & & \\
\hline \multirow{3}{*}{ I } & $\mathrm{A}$ & 1 & 2 & 3 & 59 & スチレン & $(35 / 65) *$ \\
\hline & B & 1 & 2 & 3.3 & 42 & スチレン & $(35 / 65) *$ \\
\hline & $\mathrm{C}$ & \multicolumn{6}{|c|}{ 市販不飽和ポリエステル塗料 } \\
\hline \multirow{6}{*}{ II } & A & 1 & 1 & 2.2 & 52 & スチレン & $1.6 / 1$ \\
\hline & B & 2 & 1 & 3.3 & 50 & スチンン & $1.6 / 1$ \\
\hline & $\mathrm{C}$ & 2 & 1 & 3.3 & 50 & MM A & $2 / 1$ \\
\hline & $\mathrm{D}$ & 2 & 1 & 3.3 & 50 & D A P & $2 / 1$ \\
\hline & $\mathrm{E}$ & 2 & 1 & 3.3 & 72 & ST/MMA (6/4) & $1.6 / 1$ \\
\hline & $\mathrm{F}$ & 2 & 1 & 3.3 & 72 & ST/VAC (8/2) & $2 / 1$ \\
\hline
\end{tabular}

表-1 区分 I の試料について溶剂抽出法と加水分解法

表-1＼cjkstart実験Ｉのポリエステル組成表

（註）ポリエステル成分は当量比（MA：マレイン酸, $\mathrm{PA}:$ フタル酸, $\mathrm{PG}:$ プロピレングリコール) 不飽和基モル比はモノマ/ーポリェステル, *印（）内は重量比を示す（ST：スチレン, MMA : メチルメタクリレート, DAP : ジアリ ルフタレート, VAC : 酢酸ビニル) 
で求めたゲル分率の值を図-4，5 亿示す。また区分IIの 試料は $1.5 \mathrm{Mrad}$ の条件を省き, 溶剤抽出法のみでゲル 分率を求的た。气の値を図-6 示す。これらの中の主

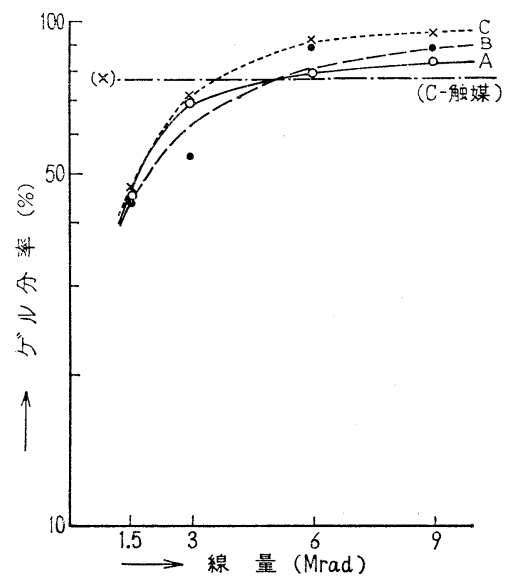

図-4 溶剤抽出法によるゲル分率

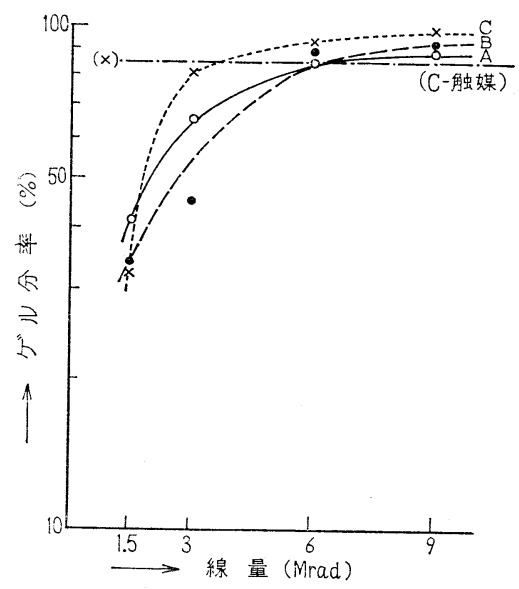

圆-5 加水分解法によるゲル分率

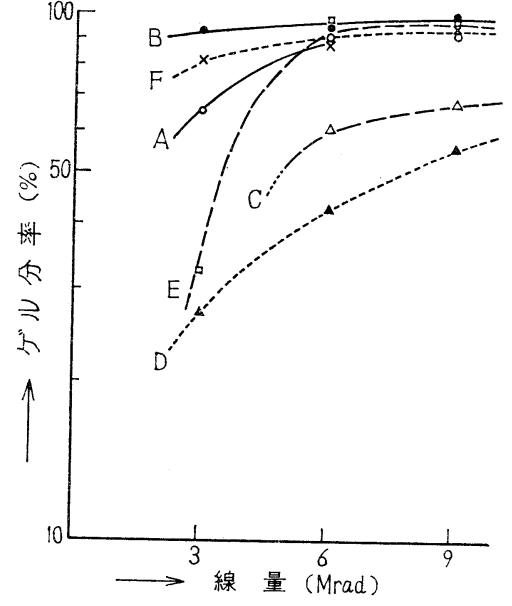

図-6 組成别各線量でのゲル分率

なものをプラスチック板に塗布し, 電子線照射および触 媒で硬化させてるのの性状の比較を表-2 に示す。な掠 耐衝撃性やエリクセン押出試験は電子線のため素地プラ スチックの物性が変化したので比較できなかった。

図-4，5 からダル分率はいずれの方法でも注湆並行し て物り，表-2 の試験結果と㐫わせて，操作のより簡便 な溶剤抽出法によるゲル分率が硬化判定に使光ると判断 した。実用硬化域は添湆㐌ル分率 $85 \%$ 以上であり，不 飽和ポリエステルーモノマー系の多くは線量 $6 \mathrm{Mrad}$ 以 上で実用的に硬化し, 触媒硬化の場合に比べて付着性・ 耐薬品性とくに耐水性が向上している。ポリェステルの 組成やモノマーの種類は明らか飞硬化線量深影を及滰を すが，乤の詳細は別の機会に述べる。

\section{5. 実験 II 異なる加速器による照射}

多くの加速器はその個々について線量率をか学るのは 容易ではない。このため出力が異なり，乙たがって線量

表-2 電子線硬化と触媒硬化のポリエステルの性状比較

\begin{tabular}{|c|c|c|c|c|c|c|c|c|c|c|c|c|}
\hline \multirow{2}{*}{\multicolumn{2}{|c|}{ 項 }} & \multirow{2}{*}{ 目 } & \multicolumn{5}{|c|}{ 電子線 硬 化 (6 Mrad) } & \multicolumn{5}{|c|}{ 触 } \\
\hline & & & II - A & II - B & II - E & II - F & $\mathrm{I}-\mathrm{C}$ & II $-\mathrm{A}$ & II $-\mathrm{B}$ & II - E & II $-\mathrm{F}$ & $\mathrm{I}-\mathrm{C}$ \\
\hline \multirow[t]{2}{*}{ 鉛 } & 筆 & 硬＼cjkstart度 & $\mathrm{H}$ & $3 \mathrm{H}$ & $3 \mathrm{H}$ & $2 \mathrm{H}$ & $3 \mathrm{H}$ & $\mathrm{H}$ & $3 \mathrm{H}$ & $\mathrm{H}$ & $2 \mathrm{H}$ & $3 \mathrm{H}$ \\
\hline & & 酸 & 5 & 5 & 5 & 5 & 5 & 5 & 4 & 5 & 5 & 4 \\
\hline \multirow{3}{*}{$\begin{array}{l}\text { スポッ } \\
\text { トテス } \\
\text { ト }\end{array}$} & & ルカリ & 3 & 4 & 4 & 3 & 4 & 3 & 3 & 3 & 3 & 3 \\
\hline & & ルオール & 4 & 5 & 4 & 5 & 4 & 2 & 4 & 4 & 5 & 4 \\
\hline & & アセトン & 2 & 5 & 1 & 1 & 3 & 1 & 3 & 2 & 3 & 3 \\
\hline 沸 & 水 & 験 & 15 & 35 & 35 & 50 & 30 & $<5$ & $<5$ & 5 & $<5$ & $<5$ \\
\hline 付 & 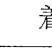 & 性 & $100 / 100$ & $90 / 100$ & $100 / 100$ & $100 / 100$ & $100 / 100$ & $0 / 100$ & $0 / 100$ & $100 / 100$ & $50 / 100$ & $30 / 100$ \\
\hline
\end{tabular}

（註） 耐熱グレード ABS 板に塗布して試験

スポットテストは 5 点法判定, 沸水試験はブリスターまたはハガレまでの時間（単位時間） 
率の異なる 3 種類の加速器により, 次の 4 水準でそれぞ れ総線量 1.5，3，6 Mrad の照射を行なった。

照射 I : 線型加速器, $6 \mathrm{MeV}$, 平均 $50 \mu \mathrm{A}$

線量率推定 $0.025 \mathrm{Mrad} / \mathrm{sec}$

照射 II : バンデグラフ加速器, $0.8 \mathrm{MeV}, 15 \mu \mathrm{A}$ 線量率不明礁

照射 III：共振変圧型加速器, $1.7 \mathrm{MeV}, 1 \mathrm{~mA}$

線量率推定 $0.13 \mathrm{Mrad} / \mathrm{sec}$

照射 $\mathrm{V}$ : 共振变圧型加速器, $1.7 \mathrm{MeV}, 6 \mathrm{~mA}$

線量率推定 $1.43 \mathrm{Mrad} / \mathrm{sec}$

表-3 実験吕忤よび亚のポリエステル組成表

\begin{tabular}{|c|c|c|c|c|c|c|c|}
\hline \multirow{2}{*}{ 記号 } & \multicolumn{3}{|c|}{ ポリエステル } & \multirow{2}{*}{$\begin{array}{l}\text { 米リエ } \\
\text { ステル } \\
\text { 酸価 }\end{array}$} & \multirow{2}{*}{ モノマー } & \multirow{2}{*}{$\begin{array}{l}\text { モノ } \\
\text { 一 モル } \\
\text { 比 }\end{array}$} & \multirow{2}{*}{$\begin{array}{l}\text { 不飽和 } \\
\text { 基モル } \\
\text { 比 }\end{array}$} \\
\hline & M A & P A & $P G$ & & & & \\
\hline A & 2 & 1 & 3.3 & 57 & ST/MMA & $1 / 1$ & 1. $6 / 1$ \\
\hline B & 2 & 1 & 3.3 & 57 & ST/MMA & $3 / 2$ & $2 / 1$ \\
\hline $\mathrm{C}$ & 2 & 1 & 3.3 & 57 & $\mathrm{ST} / \mathrm{AN}$ & $2 / 1$ & $2 / 1$ \\
\hline $\mathrm{D}$ & 2 & 1 & 3.3 & 57 & $\mathrm{ST} / \mathrm{AN}$ & $2 / 1$ & $3 / 1$ \\
\hline $\mathrm{E}$ & 2 & 1 & 3.3 & 57 & $\mathrm{ST} / \mathrm{VAC}$ & $20 / 1$ & 1. $6 / 1$ \\
\hline
\end{tabular}

（註）不飽和基モル比はモノマー/ポリエステルを示 す。

モノマーの記号説明 ST：スチレン, MMA：

メチルメタクリレート, $\mathrm{AN}:$ アクリロニトリ

ル, VAC : 醀酸ビ $=ル$

試料の組成は 表-3 に示するので，その硬化物のゲル 分率測定結果を表-4 に，またその中の試料 $\mathrm{E}$ を図-7 に グラフで示す。硬化度は I > II > II > N の順となり，線 量率の影響があることが予測される。しかし条件II と III の線量率の比較が明らかでなく，3 項に述べたような線 量計算上の疑問もあるので，正しくは 1 種類の加速器で 水準を変えて照射実験を行ならべきであると判断した。

この実験に用いた組成のものをさらに塗膜硬化用に設 計された $300 \mathrm{keV}, 10 \mathrm{~mA}$ の工業用加速器で照 射した が，アルミ製シャーレに流し込んだ試料では低ェネルギ 一のため透過能が不足して底部まで硬化せず，またテス

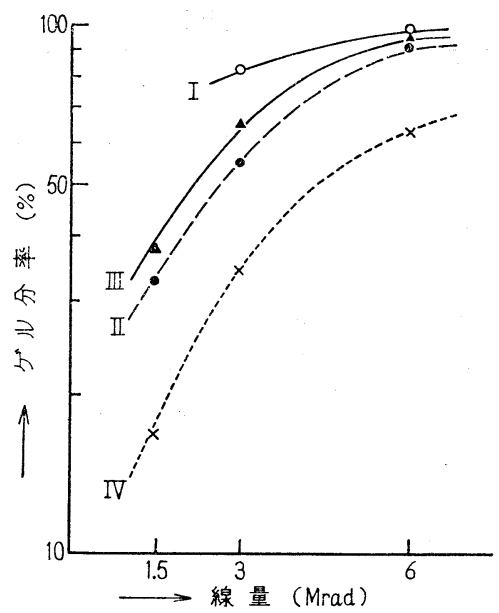

図-7 加速器条件別ゲル分率（組成 E）

トピースに薄膜に塗装した試料ではハガした塗膜量が不 足で，いずれもゲル分率測定ができず，上記の条件のも のと直接比較はできなかった。しかしテストピースでは $3 \mathrm{Mrad}$ でも核とんど表面粘着なく硬化し，Burlant や Hoffmanのいら高線量率下では線量率依存性が失なわれ るといら傾向を予測させる結果であった。

\section{6. 実験 III 線量率依存性の検討}

硬化に詨する線量率の影響を把握するために電流值が 可変の加速器で条件を変えて照射した。試料は実験 II 同じ表-3 の組成を用い, 次の条件で照射した。

加 速 器: 共振变圧型加速器

加速電圧 : $2 \mathrm{MeV}$ ピーク

電子電流 $: 1 \mathrm{~mA} \sim 6 \mathrm{~mA}$

照射距離 : $20 \mathrm{~cm}$ 拈よび $35 \mathrm{~cm}$

線量率: $0.132,0.40,1.00,1.43 \mathrm{Mrad} / \mathrm{sec}$

総 線 量: $3,6,9 \mathrm{Mrad}$

硬化物のゲル分率測定結果を表-5 ならびに 総線量別 に図-8〜10 に示す。 3 执よび $6 \mathrm{Mrad}$ では線量率が高 い汪ど硬化が拈くれるが，9Mrad ではすでに反応は飽

表-4 各種加速器での照射に拉けるゲル分率

\begin{tabular}{|c|c|c|c|c|c|c|c|c|c|c|c|c|}
\hline $\begin{array}{ll}\text { 線 量 } \\
\end{array}$ & & $1.5 \mathrm{~N}$ & $\mathrm{rad}$ & & & $3 \mathrm{M}$ & & & & $6 \mathrm{M}$ & & \\
\hline 組 照 射 & I & III & III & $\mathbb{N}$ & I & III & III & $\mathbb{N}$ & I & III & III & N \\
\hline A & - & 20.4 & 26.4 & $(-)$ & 91.0 & 47.0 & 49.5 & 17.0 & 93.8 & 91.4 & 87.7 & 40.5 \\
\hline B & - & 13.6 & 19.4 & $(-)$ & 92.0 & 24.8 & 36.4 & 18.8 & 99.0 & 91.2 & 92.8 & 46.0 \\
\hline $\mathrm{C}$ & - & 19.8 & 28.6 & 18.7 & 81.6 & 51.4 & 73.0 & 22.8 & 93.6 & 91.7 & 98.3 & 84.0 \\
\hline $\mathrm{D}$ & - & (3.7) & 15.0 & $(-)$ & 84.5 & 22.6 & 36.8 & 15.9 & 98.0 & 83.1 & 87.8 & 38.1 \\
\hline $\mathrm{E}$ & - & 32.5 & 37.8 & 16.8 & 81.7 & 55.0 & 64.5 & 33.9 & 97.6 & 90.3 & 97.2 & 61.8 \\
\hline
\end{tabular}

(註). 照射条件 I の $1.5 \mathrm{Mrad}$ は実施せず，他の（一）印はゲル化せず測定不能 
表-5 共振変圧型加速器による各線量率に拈けるゲル分率

\begin{tabular}{|c|c|c|c|c|c|c|c|c|c|c|c|c|}
\hline \multirow{2}{*}{ 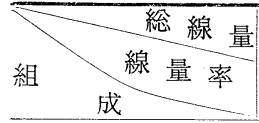 } & \multicolumn{4}{|c|}{$3 \mathrm{Mrad}$} & \multicolumn{4}{|c|}{$6 \mathrm{Mrad}$} & \multicolumn{4}{|c|}{9 Mrad } \\
\hline & 0.132 & 0.40 & 1.00 & 1.43 & 0.132 & 0.40 & 1.00 & 1.43 & 0.132 & 0.40 & 1.00 & 1.43 \\
\hline A & 39.1 & 22.4 & 20.2 & 17.7 & 87.3 & 73.2 & 68.1 & 67.4 & 89.0 & 94.0 & 86.0 & 92.5 \\
\hline B & 28.1 & 17.2 & $(4.3)$ & $(5.9)$ & 88.3 & 43.6 & 34.1 & 29.4 & 92.5 & 86.4 & 80.9 & 92.5 \\
\hline $\mathrm{C}$ & 30.7 & 19. 1 & $(1.6)$ & $(2.9)$ & 85.4 & 56.5 & 36.1 & 31.5 & （欠） & 89.4 & 77.3 & 83.5 \\
\hline $\mathrm{D}$ & 15.4 & $(3.7)$ & $(-)$ & $(-)$ & 53.5 & 28.4 & 30.6 & 25.2 & 92.0 & 84.7 & 87.6 & 84.5 \\
\hline $\mathrm{E}$ & 51.5 & 32.1 & 16.0 & 14.4 & 85.2 & 73.3 & 50.0 & 49.2 & 90.0 & 93.8 & 93.4 & 90.2 \\
\hline
\end{tabular}

（註）（ ）内はゲル化不十分またはゲル化しないため精度不十分または測定不能，（欠）は試料欠損

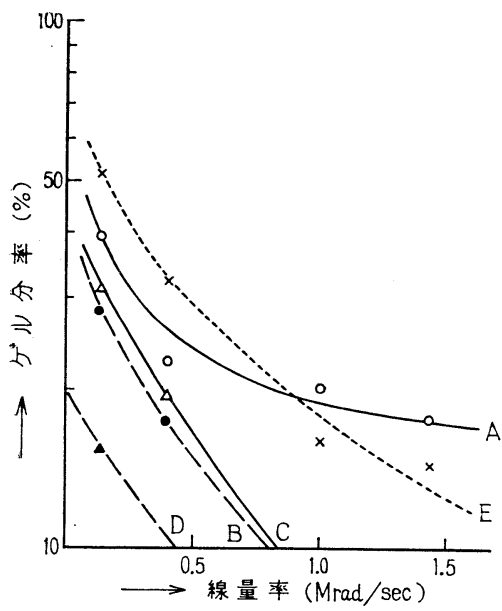

図-8＼cjkstart線量率とゲル分率 $(3 \mathrm{Mrad})$

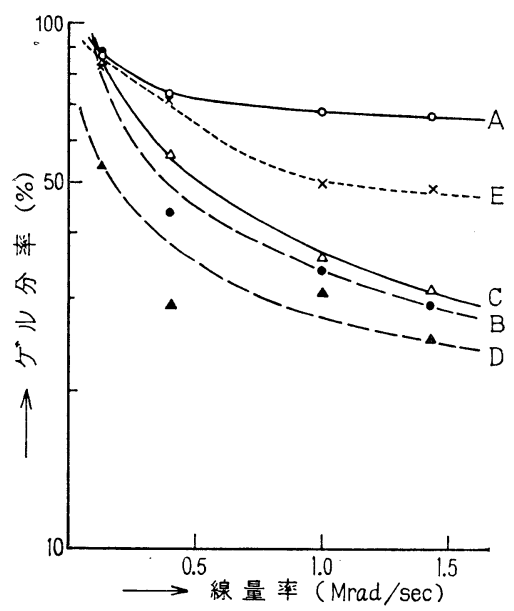

図-9 線量率とゲル分率 $(6 \mathrm{Mrad})$

和して線量率の差は見出せない。

ここで重合速度 $v$ が線量率 $I$ の $n$ 乗 $(0<n<1)$ に比 例するとして次のように抢く。

$$
v=k \cdot I^{n}
$$

一方照射による系の硬化はきわめて短時間に行なわれる

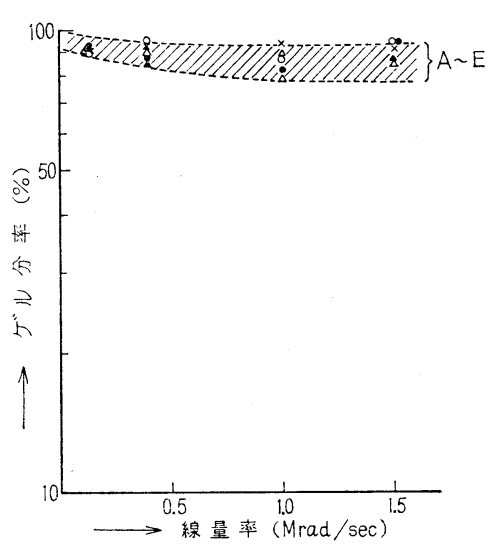

図-10 線量率とゲル分率 (9 Mrad)

ので $v$ はその間の平均速度と考えてよいから， ゲル分率 G.F. を次の形で書くことができる。

$$
\text { G. } F .=k^{\prime} \cdot v \cdot t
$$

$K=k \cdot k^{\prime}$ と特けば (1), (2) 式から

$$
G . F .=K \cdot I^{n} \cdot t
$$

ここで $I \cdot t=D$ は総線量であるから（3）式はさらに

$$
G . F .=K \cdot I^{n-1} \cdot D
$$

と書ける。この式が成立するためには反応の期間を通じ て $v$ は大きく変動しないことが前提になるから，反応が すでに飽和した $9 \mathrm{Mrad}$ の值に適用するのは妥当でな い。また $3 \mathrm{Mrad}$ の值は反応が十分定常的に進行するに 至ってないとみなされ，また硬化不十分のためゲル分率 の測定精度も低いと思われる。そこで中間の, 比較的定

表-6 一次回帰式および $n$ 值

\begin{tabular}{c|c|c|c}
\hline 組 成 & - 次 回 㷌 & $n^{\prime}$ & $n$ \\
\hline $\mathrm{A}$ & $y=9+4-0.11 x$ & -0.11 & 0.89 \\
$\mathrm{~B}$ & $y=9.8-0.48 x$ & -0.48 & 0.52 \\
$\mathrm{C}$ & $y=9.9-0.43 x$ & -0.43 & 0.57 \\
$\mathrm{D}$ & $y=7.4-0.30 x$ & -0.30 & 0.70 \\
$\mathrm{E}$ & $y=9.4-0.24 x$ & -0.24 & 0.76 \\
\hline
\end{tabular}


常的に反応が進行していると思われる $6 \mathrm{Mrad} の$ 場合の ゲル分率の值を用いて回帰分析を行なった。

(4) 式に拈いて $n^{\prime}=n-1, G . F .=A \cdot I^{n \prime}$ とし

$$
x=10(\log I-5) . \quad y=10(\log G . F .-1)
$$

と数值变換して直線回帰式を求め, $n$ を算出した。その 結果は表- 6 に示すよ し, この程度の線量率域では線量率に関する $1 / 2$ 乗則は くずれて 1 乗に近づくこと, その依存性は系の組成によ って変化することが認められた。

以上の実験は主として高ェネルギーでむしろ低線量率 の研究用加速器によったが, 線量率依存性の存在が認め られたので，塗料としての実用組成の開発にあたっては 低エネルギー大電流の工業用加速器で追試することが必 要である。

終りに, この実験にあたって加速器と線量計算に関し て種々御教示をたまわり，照射の便宜をはかって頂いた 大阪府立放射線中央研究所はじめ関係の各位に厚く感謝 の意を表する。

\section{文献}

1）たとえば 日本原子力産業会議：放射線化学調査 団報告, 1966 年 4 月ほか

大島・田畑：化学経済（1 月） 86 (1967)
E. D. Gantt \& D. A. Trageser : "Industrial Application of Electron Accelerators." UKAEA Symposium Report, Paper 7, Nov. (1967)

2) たとえば K. H. Morganstern : Paint \& Var. Prod., 57 [6], 67 (1967)

J. Oliver : Products Finishing, 32 [4], 48 (1968) 電子線硬化特集：塗装技術，7 [12]，29（1968）

3) A. Charlesby et al.: Proc. Royal Soc., A-244, 54 (1958)

4) W. Burlant \& J. Hinsch : J. Polym. Sci., Part A, 2, 2135 (1964) ; J. Polym. Sci., Part A, 3, 3587 (1965)

5) A. S. Hoffman \& D. E. Smith : Mod. Plastics, 43 [10], 111 (1966)

6) K. R. Clark : Forest Prod. J., 14 [2], 51 (1964)

7) 重松：放射線高分子, 2 [4]，3(1960)

8) Brit. Patent 949, 191, Feb. 12 (1964)

9) U.S. Patent $3,247,012$, Apr. 9 (1966)

10）日本特許 295392 （特公, 昭 36-17846, Sept. 29, 1961)

11) A.Charlesby-団野浪訳：放射線と高分子, p. 27 , 朝倉書店 (1962)

12) そのほか加速器関係については 雨宮：放射線化学入門 (上), p. 153, 丸善 (1962) 団野: 実験化学講座 (続) (4), 核化学々放 射化 学, p. 575 , 丸善 (1966)

13) B. Alt : Kunststoffe, 53 [10], 801 (1963)

14) 後藤 - 鈴木 : 高分子化学, 12 [122], 258 (1955)

\section{色材協会誌 Vol.42 No.3 （予告）}

報文

顔料が塗膜の光沢に与える影響 (第 3 報) (堺化工(株)) 川端 旭 キナクリドン系顔料に関する研究(第 4 報) ·(大日本インキ化工(株)） 高木邦彦外

実験ノート

漆皮膜の示差熱分析・ (東北工業技術試験所) 佐 藤 誠

\section{資 料}

塗料と公害防止について (大日本塗料(株)）西田 滋

\section{色材サロン}

技能訓練の今後. ·((株)副島塗装店) 副島 啓 治

文献・特許抄録 